\title{
Discrepancies in Fiscal Architecture: Context and Causes of Devolution Reforms' Outcomes in Khyber Pakhtunkhwa, Pakistan
}

\author{
Aamer Taj ${ }^{1}$, Fahad Abdullah ${ }^{2}$
}

\begin{abstract}
Based on qualitative empirical evidence from four diverse districts of Khyber Pakhtunkhwa province, this case study examines the limitations in fiscal policy of local governance reforms in Pakistan. Keeping in view the constrained redistributive system that is rooted in the governance setup at provincial and local level, fiscal architecture is analysed. The impact of abolishment of rural urban administrative divide on tax redistribution, complications in revenue generation, matters related with jurisdictional transgression in revenue collection and development expenditure, and inadequate amount of public funds for development are analysed as key factors that are presumably responsible for the defective fiscal management.
\end{abstract}

Keywords: Local governance, fiscal management, revenue generation, tax redistribution, development expenditure

\section{Introduction}

General Pervez Musharraf toppled the elected government of Nawaz Sharif and Pakistan's army took over the government in 1999. General Musharraf became self-proclaimed Chief Executive of Pakistan under the second PCO (Provisional Constitution Order) on October 14, 1999. Later, he also took over the office of the President of Pakistan on June 20, 2001. In the pursuit of seven-point agenda proposed by General Musharraf, NRB (National Reconstruction Bureau) was established with an aim of devolving political power to the grass root level. NRB was given the responsibility to design the devolution of power plan for restructuring Pakistan's political and administrative sub-national governance setup. According to the agenda, this devolution of power program was aimed at politically empowering the citizens, decentralization of administrative authority, decentralization of professional functions, and distribution of

1 Assistant Professor, Institute of Management Sciences, Peshawar. Email: aamer.taj@imsciences.edu.pk 2 Assistant Professor, Institute of Management Sciences, Peshawar. Email: fahad.abdullah@imsciences. edu.pk

ARTICLE HISTORY
\begin{tabular}{lll}
20 Mar, 2017 Submission Received & 17 Apr, 2017 & First Review \\
\hline 8 May, 2017 Revised Version Received & 18 May, 2017 & Second Review \\
\hline 29 May, 2017 Revised Version Received & 3 Jun, 2017 & Accepted
\end{tabular}


financial resources to the provinces and the local governments. Following the program, local governments were formed at three levels (District, Tehsil and Union) through a Presidential Ordinance - LGO (Local Government Ordinance) in August 2001 and the 17th constitutional amendment promulgated by Musharraf in December 2003 whereby a series of political, administrative and fiscal changes were brought about in local, regional, and provincial governance mechanisms.

This paper examines the limitations of fiscal decentralization in the context of local governance in Pakistan. Against the very essence of federalist structure enshrined and protected in the constitution of Pakistan ${ }^{3}$, the local government reforms of 2001 were uniformly designed and implemented in all four provinces of Pakistan by the federal government under the patronage of military regime. Fiscal management is one of the major bones of contention in sub-national politics of federal states. The case of Pakistan is no different. It was realized soon after the implementation of LGO 2001 that in addition to political and administrative discords between various interest groups at local, regional and national levels, inherent and inherited discrepancies in the fiscal management system of local governance were responsible for its ineffective and inefficient outcomes. This study primarily focuses on examining the structural flaws associated with the fiscal aspect of decentralization program. In particular, the paper unveils and explains incongruence of reforms' fiscal policy with the ground realities in the embedded redistributive system practiced by the civil administration and various levels of government in Pakistan.

\section{Methodology}

This study rests on primary and secondary data for analysis. Case specific literature review is based on empirical studies conducted by independent analysts, policy advocacy organizations, and international development agencies. In addition to the review of literature on local government reforms, first hand raw data have also been collected and analysed in order to assess the phenomena under investigation in a case study of Khyber Pakhtunkhwa province of Pakistan. A total of 45 key informant interviews (See Table 1) were conducted with local public officials that included appointed officials from civil administration and elected local government representatives in two phases i.e. July-September 2008 and December 2009. Four districts i.e. Peshawar, Swabi, Abbottabad and Mansehra were selected from Khyber Pakhtunkhwa for this case study.

The rationale for selection of the province and the districts within the province

3 Articles 140 (A) in Constitution of Pakistan states that 'each Province shall, by law, establish a local government system and devolve political, administrative and financial responsibility and authority to the elected representatives of the local governments' 
is based on contextual reasons. As a native, the principal author capitalized on easy access to the local public officials. Use of personal contacts and then building on snowballing techniques for getting access to other interviewees was relatively easier for the author in Khyber Pakhtunkhwa province. Four districts, their respective towns and union councils from rural and urban areas were purposively selected in order to grasp the impact of variations in terms of size of population, socio-economic diversity, social infrastructure, economic development indicators, public funds availability, and geography. The aim was to formulate a representative sample so that the empirical evidence could be spell out not only the similarities but also the differences in the outcomes of fiscal policy of reforms. Since the data for analysis is collected from Khyber Pakhtunkhwa province only, authors do not claim the findings of the study to be generalizable for the whole country. The idea is to explain the nature of issues peculiar to the diverse regions of Khyber Pakhtunkhwa province only.

Processed data in form excerpts and quotations from key informant interviews are utilized as empirical evidence in this paper. Employees from departments of health, education, municipal administration, finance and planning and office of District Coordinating Officer (DCO) were interviewed. Similarly, Nazim (Mayor) and Naib Nazim (Deputy Mayor) were interviewed at District, Tehsil (Town) and Union Council (UC) levels along with Councillors (Members of Union Councils), and Union Secretaries. Following the guidelines for ethically considerate social research, identity of respondents has been kept anonymous.

Table 1: List of Interviewees

\begin{tabular}{|c|c|}
\hline S. No & Designation of Interviewee \\
\hline 1 & Administrative Officer Town 3, Peshawar \\
\hline 2 & Naib Nazim Town 3, Peshawar \\
\hline 3 & Nazim, Town 3, Peshawar \\
\hline 4 & District Naib Nazim, Mansehra \\
\hline 5 & Town Officer, Town 3 Peshawar, Executive Engineer (Civil) \\
\hline 6 & Town Municipal Officer, Town 3, Peshawar \\
\hline 7 & Chief Officer, Town 3, Peshawar \\
\hline 8 & Union Council Nazim, Union Council Matta, Tehsil Shabqadar \\
\hline 9 & Union Secretary, Union Council 36, University Town, Town 3, Peshawar \\
\hline 10 & General Councilor / Member Union Council 36, Town 3, Peshawar \\
\hline 11 & Union Secretary, Union Council 81, Town 3, Peshawar \\
\hline 12 & Nazim Union Council Shaheen Town, Town 3, Peshawar \\
\hline 13 & Secretary Local Government (Senior Bureaucrat), Local Government Secretariat, Peshawar \\
\hline
\end{tabular}




\begin{tabular}{|c|c|}
\hline 14 & $\begin{array}{l}\text { Deputy Director, Services and Works Department, District Peshawar (Previously known as } \\
\text { C\&W Department) }\end{array}$ \\
\hline 15 & Assistant Director, Services and Works Department, District Peshawar \\
\hline 16 & Director Coordination, City District Peshawar \\
\hline 17 & District Nazim Peshawar \\
\hline 18 & EDO (Finance and Planning), District Abbottabad \\
\hline 19 & District Officer (Female) (Schools and Literacy Department) Abbottabad \\
\hline 20 & $\begin{array}{l}\text { Deputy District Officer (Female Education) (Schools and Literacy Department) Abbotta- } \\
\text { bad }\end{array}$ \\
\hline 21 & Superintendent - LTR (License, Transport Terminal and Rent), TMA Mansehra \\
\hline 22 & Assistant Tehsil Officer (Regulation), TMA Mansehra \\
\hline 23 & TMO Tehsil Mansehra \\
\hline 24 & EDO (Health) Abbottabad \\
\hline 25 & DCO Abbottabad \\
\hline 26 & ACO (Assistant Coordinating Officer), Abbottabad \\
\hline 27 & EDO (Finance and Planning) Peshawar \\
\hline 28 & EDO (Elementary and Secondary Education), District Swabi \\
\hline 29 & DO (Revenue), Finance and Planning Department, District Swabi \\
\hline 30 & District Naib Nazim, District Swabi \\
\hline 31 & TMO, Tehsil and District Swabi \\
\hline 32 & UC Nazim Sara China, District Swabi \\
\hline 33 & Tehsil Nazim, (Small) Lahore, District Swabi \\
\hline 34 & EDO Education, Peshawar \\
\hline 35 & Naib Nazim, Town 2, Peshawar District \\
\hline 36 & District Nazim, Swabi \\
\hline 37 & UC Nazim, Chaknodia, District Swabi \\
\hline 38 & UC Nazim Sara China, District Swabi \\
\hline 39 & UC Nazim, Havailian Urban, District Abbottabad \\
\hline 40 & Tehsil Nazim, Havailian, District Abbottabad \\
\hline 41 & UC Nazim, UC City No. 3, Mansehra \\
\hline 42 & UC Nazim, UC Tanda, District Mansehra \\
\hline 43 & District Naib Nazim, Mansehra \\
\hline 44 & District Naib Nazim Peshawar \\
\hline 45 & UC Nazim, Tarnab Farm, District Peshawar \\
\hline
\end{tabular}


Although several years old, the primary data are still valid in a sense that the design of tax redistribution and fiscal transfer system practiced at provincial and local level in form of Provincial Finance Commission (PFC) ${ }^{4}$ award remained more or less the same till 2015. Some changes ${ }^{5}$ were made in the formula for PFC awards however due to non-existence of elected local governments between 2009 and 2015, the data remains current as far as the main factors under investigation in this study are concerned i.e. the impact of abolishment of rural urban divide on tax redistribution, complications in revenue generation, matters of jurisdiction for revenue collection and development expenditure, and de facto control over the management of public funds for local governments. Latest development (2015 onwards) pertaining to the significant increase in the amount of public funds allocation for local governments is discussed in section 7 of the paper.

\section{Theoretical Framework}

Matters related with local public finance are political in nature (Smith, 1985) and hence motivations that shape up economic behaviour are hardly distinguishable from motivations that stimulate political behaviour. Fiscal management is therefore a critical and decisive component of programs on federalism and decentralization. Rationale for decentralized governance rests on the principle that governance is best when the local representatives are accountable to citizens. In addition, the autonomy and control over local taxes also determine the effectiveness of local governance. Fiscal decentralization is positively associated with enhanced quality of governance (Huther \& Shah, 1998; De Mello \& Barenstein, 2001). Some of the indicators of good governance are citizens' participation in decision making, accountability of public officials, efficient economic management, and reduced corruption. Local sources for tax generation cannot be relied upon when it comes to meeting the social services needs of citizenry. Therefore, local governments are not expected to be completely self-sufficient as far as the revenue collection for public programs is concerned. Local governments usually sustain on a combination of self-generated revenues and funds' transfers from higher levels of government. In case of total dependence of local

4 Provincial Finance Commissions (PFCs) were established under the article 120-A of Constitution of Pakistan for each of the four provinces in year 2001. PFCs were mandated to devise formulae for the distribution of resources among the districts of province in order to minimize poverty and income inequality. 5 Since 2002, the Khyber Pakhtunkhwa government has given five PFC Awards. The first three were of an interim nature i.e. for a one-year period while the fourth and the fifth, covering the years 2005 to 2011, were for three-year periods. The 6th award has yet to be announced. In the first three awards, the horizontal distribution formula was: 50\% for population, 25\% for backwardness and $25 \%$ for lag in infrastructure. In subsequent two awards (4th and $5^{\text {th }}$ ), the weightage of population was raised to $60 \%$ while that of backwardness and lag in infrastructure was reduced to 20\% each. \{Source: Khan, M. Z. (February 13, 2017). Khyber Pakhtunkhwa struggling with a new equitable PFC formula. Dawn Retrieved from https://www.dawn.com/news/1314514\} 
governments on higher levels of government for public funds, the accountability of local politicians to their electorate reduces significantly (Rodden, 2002; Khemani, 2004). Consequently, the mechanisms practiced for public accountability are affected adversely because no level of government takes the responsibility for ineffective and inefficient nature of public expenditure and social services delivery.

As a matter of course, it always goes against the vested interest of a local politician to levy and charge taxes in his/her electorate; alternately it is easier and more rewarding (politically) to demand more funds from the higher level of government (Jones, 1978). In such cases, local politicians serve merely as intermediaries between citizens and higher level of governments. It is essential to compare constraints faced by an appointed public official with those of an elected office bearer. Revenue generation through existing and new taxes, raising the tariffs, and inclusion of more tax payers to the existing tax net is an uphill task for a political office bearer. The reason is simple and obvious; elected politicians don't want to lose vote banks. That is why politicians are naturally inclined towards demanding more funds from the higher level of government instead of devising strategies to generate own revenues. On the other hand, however, it is easier for appointed public officials to collect user fee from consumers of public services simply because they don't need votes to retain their tenure in office. In other words, they can enforce their authority as collector of taxes without worrying about its political repercussions.

Local tax generation is quite advantageous for sustainable development e.g. own source revenue makes the local authorities and citizens more autonomous in its expenditure (Bardhan \& Mookherjee, 2006) however locally generated public money is usually insufficient to be spent on large scale development programs such as education or health services (Bardhan, 2002). Besides, revenue generation through taxes and user fee is a highly intricate job. Ajaz and Ahmad (2010) studied the effects of corruption and governance on total tax revenues using panel data set for 25 developing countries over the period 1990-2005. They concluded that corruption has adverse effects on tax collection while good governance contributes to better performance. This leads us to a safe assumption that reduction in corruption is pivotal for rebuilding tax payers' trust; it will eventually lead to enhanced revenues, better fiscal management, and inclusive development.

Theoretical discourse highlighting the correlation between decentralized governance, improved public accountability, reduction in corruption, citizens' willingness to pay taxes for social services, and sustainable efficiency in fiscal management lays the foundation of analytical framework for this study. The discourse converges on a broader conclusion that in order for local governments to perform efficiently, their de facto discretion over the expenditure of funds transferred from higher level of 
governments and their ability to enhance self-generated revenues are some of the key pre-requisites. It is argued that better accountability mechanisms improve efficiency in fiscal management however citizens can hold local representatives accountable only when the local representatives are at the helm of decision making process and are able to function autonomously in their respective domain. Next section presents an overview of fiscal policy of local government reforms and identifies the limitations of existing research on the topic.

\section{An Overview of Fiscal Reforms}

In the local government reforms of 2001, some of the fiscal functions and authorities were devolved from provincial bureaucracy to the three tiers of local governments, which included revenue generation through existing local taxes, imposition of new taxes and user fees, and public sector recurring and local developmental spending. The Local Government reforms envisaged formula based fiscal transfers to the districts through Provincial Finance Commission (PFC) awards (Charlton, Ebel, Mukhtar, Scott, \& Vaillancourt, 2002). In addition, local governments were also allowed and encouraged to levy local taxes and user fees from a specified list. For promotion of trade and commerce, the import/export tax (Octroi) on the inter-district transportation of goods was abolished through the local government reforms. According to the plan, the local governments were not allowed to incur any debt to finance their expenditures. The plan apparently encouraged the district and lower levels of government to generate their own resources in accordance with their capacity and jurisdiction.

The fiscal and administrative affairs in previous local government systems (such as Local Government Ordinance 1979) were dealt with primarily by the civil bureaucracy. A report published by Water and Sanitation Program for South Asia (1999) mentions that the earlier local government reforms failed to establish an adequate fiscal transfer system as those local councils that were mostly dominated by the civil administration, were unable to perform even the limited expenditure functions assigned to them. The case of devolution reforms of 2001 was not much different. The ten members PFC comprised of Provincial Finance Minister, three senior federal bureaucrats (provincial secretaries), three professional members from the private sector appointed by the provincial Governor, and three members from the elected local governments. It is believed that the federal government retained the control over the financial management of the elected local governments across the whole country because the representation of provincial and local government in PFC was negligible. The PFC determined the non-discretionary inter-governmental fiscal transfers from the provinces to the local government. The bulk of local government resources were mainly the fiscal transfers from provincially appointed Provincial Finance Commissions - up to $98 \%$ in some 
cases (ICG, 2004).

The elected local governments had very limited discretion over their budgetary resources. Hasnain (2008) explains that the provincial allocable amount was transferred to the local government broadly under two separate block grants; one for recurring expenditures which constituted approximately $88 \%$ of the allocable amount and the remainder for development funding with no de jure discretion to local governments to re-allocate funds across these two heads. In other words, fiscal decentralization had just been paid lip service and local governments relied almost solely on higher tiers of government for their financial requirements and development expenditures. Town Municipal Administration (TMA) ${ }^{6}$ had been given some revenue raising authorities but with strings attached, which significantly contained their fiscal autonomy and obstructed their effectiveness and efficiency. TMAs' revenue from own sources (e.g. the parking fee, cattle market fee, and tax on transfer of immovable property) were not allocated to any functional unit of TMA for instance water fees were not earmarked for water services provision, in fact the revenue generated from water provision would become part of the overall TMA pool of revenues (Nayyar-Stone et al., 2006). Such pool arrangement provided no incentives for the local officials to improve the tax or user fee collection.

Apparently, the local governments had the appropriation authority over their fiscal receipts which included revenues transferred to them from the province. However, through various administrative orders, the local governments were often directed to emulate the historic salary allocations as well as various appropriations to operational expenditures in accordance with the previous outlays (Cyan, 2007). Cheema, Khwaja, and Qadir (2005) explained that certain budgetary heads of expenditures were retained at the provincial level for instance most of the employees in the administrative departments remained provincial employees therefore the District government could not create or reduce those posts or adjust their salary structure. Hence, a large fraction of the district budget was already fixed earlier. For education department that spent around $90 \%$ of its non-development budget on salaries, this was a significant factor limiting the extent of decentralization (ibid). Such constraints, among many others, compelled the spending patterns of local councils to be path dependant and as such local government representatives found it hard to improve their revenue raising and resource allocation capacities. Local councils' involvement in fiscal decision-making was also insignificant and nominal. Cyan and Porter (2004) explained that the law prescribed the council's role in budgeting but this function was led by the executive

6 Tehsil/Town Municipal Administration was the middle tier of the local government system. Municipal services such as water, sanitation, street lights, public parks and cattle market management were assigned to the Tehsil administration. 
(civil administration) in a way that marginalized the local council. For instance, Williamson, Ahmad, and Smith (2005) argue that in the allocation of ADP (Annual Development Plan) fund, the EDO of Finance and Planning Department always dominated the budgeting authorities.

Other than the lack of fiscal autonomy, the scarcity of development funds also obstructed fiscal efficiency in local governance. For instance, ADP funds distributed among the Union Councils by the higher levels of government mostly went into a large number of small projects because when the district developmental budget was divided equally among Union Councils, it became too scant to be spent on any substantial project. Three main issues are worth considering over here. Firstly, local governments were highly dependent on the higher tiers of government for their fiscal arrangements; secondly, the traditional institutional procedures coerced the spending patterns of local councils to be path dependant; and thirdly, the design of fiscal decentralization left the TMA and Union Councils with inadequate funds that were hardly sufficient to be spent on any substantial development project.

Key findings in studies on analysis of fiscal policy of local government reforms reveal that elected officials' lack of discretion and authority in fiscal management, local governments' total dependence on funds from higher levels of government and limited availability of public funds were some of the major reasons behind the failure of fiscal policy. The existing research however does not sufficiently explain the impact of other associated determinants such as administrative and political structural changes. Current research on the topic barely explains the reasons why despite assignment of numerous revenue raising functions to the local government, the dependence on fiscal transfers from higher level of government was not reduced while the scarcity of public funds for recurring and development expenses continued to adversely affect social services delivery and developmental projects. From the generic and case-specific literature review of local government reforms, several themes were identified. Issues in revenues collection and funds allocation mechanisms; major financial weaknesses in devolved public sector departments; jurisdictional overlaps among the domains of local government and appointed public sector employees; impact of integration of rural and urban areas for administration; and priorities in social services delivery and developmental projects were some of the identified themes that were used for formulation of interview questions. Primary data collected via interviews offers supplementary explanations and perspectives; the same are elaborated in next section. 


\section{Dissonance in Fiscal Policy: Evidence from Khyber Pakhtunkhwa Province}

The case specific literature review illustrates that the provincial governments retained their influence in financial resource allocation and the mechanism for PFC award allowed very limited fiscal autonomy to the local governments. This part of the paper investigates the discontent of public officials from local government and administration in relation to the limitations of fiscal policy of local government reforms.

In an interview, the District Officer (Revenue) in Finance and Planning Department from District Mansehra specified some of the discrepancies in implementation of fiscal policy of devolution reforms. He argued that the government introduced local government reforms in year 2001 and the budget rules for local governments in 2003 , and then fiscal transfer rules in 2004. According to him, all these amendments and reforms should have been implemented simultaneously because they (officials in the Revenue Department) did not have the rules of business between the year 2001 and 2003. The officials of devolved Revenue Section in Finance and Planning Department found it difficult to work under the new arrangement in the absence of revised job description and budget rules. Since the devolution plan was designed and implemented haphazardly, the transfer of decision making powers from bureaucratic civil administration to the devolved local governments took a long time.

\subsection{Abolishment of rural urban divide and its implications for tax redistribution}

One of the legacies left by the colonial administration system was the separation of rural and urban geographical areas for administrative purposes. Rural and urban areas were demarcated geographically and were administered by the different administrative units. A somewhat similar form of rural-urban administrative division remained in place in the post-independence Pakistan until the year 2001. With the implementation of local government ordinance in 2001, the rural-urban administrative division was abolished and the municipal and administrative services were assigned to respective local government/administrations. It was learnt in this study that this administrative integration of rural and urban areas had a mixed impact on the fiscal management efficiency of local governments.

The Naib Nazim of an urban Town in Peshawar District explained that in the pre devolution period, there used to be District Councils and Municipal Corporations for municipal services. The District Councils were responsible for municipal services in rural areas while Municipal Corporations used to look after the urban areas. The District Councils used to collect Zilla (District) tax while Octroi used to be collected 
by Municipal Corporations. One of the disadvantages, according to him, for the rural areas in this local government system was that the Zilla (District) tax was now equally divided in all Union Councils of a District except for $10 \%$, which is left for District Council's expenditures. In Peshawar, 42 out of 92 UCs are urban and 48 are rural. Earlier, this District tax used to be distributed only in these 48 rural UCs whereas now it was divided among the rest of 42 urban UCs as well. However, the Octroi is still divided among those 42 urban UCs only. This dispensation is disadvantageous for the rural areas in terms of redistribution policy. Similarly, a senior officer (Superintendent- License, Transport Terminal and Rent) from TMA Mansehra believed that in their TMA, villages generate relatively more taxes (referring to the tax on the transfer of immovable property) because the purchase and sale of land is more frequent in the rural areas of their TMA as compared to cities. He believed that contrary to the general notion that tax collected at the urban areas is spent in rural areas, it is indeed the rural areas that generate more taxes, which is then spent on urban areas.

On the other hand, however the case of some urban towns and their suburban rural areas was very different where the rural areas had a relative advantage in the fiscal redistribution. For instance, TMA of Town 3 in Peshawar comprised of 21 UCs. Most of these UCs were in rural areas and quite a few in the urban. The Nazim of those UCs were mostly elected from the rural constituencies. Given the discrepancies in tax collection mechanisms, most of the revenue generated in the form of user fee was collected from the developed urban UCs of that town and this revenue was then spent for meeting the recurring expenses of all 21 UCs included in Town 3. Tehsil Havailian in Abbottabad District, the largest revenue generator (from timber markets and cattle fairs) also faced similar predicaments. The revenue generated from Havailian's urban UCs was reported to be spent on all 21 UCs of Tehsil Havailian in Abbottabad. In the rural areas where the purchase and sale of land is frequent, the revenue generated from the tax on transfer of immovable property is higher and therefore it is hard for the citizens to evade such taxes because the sale and purchase of immovable property needs registration in the TMA. Therefore, in some cases, rural areas generate more revenue than urban areas, depending on the varying frequency of sale of immovable property and composition of TMA in terms of its UC's status as rural or urban. However, on the other hand, in the rural areas where the transfers of immovable property are not frequent, the overall tax generation in the TMA was found to be very low.

\subsection{Embedded complications in revenue generation}

User fee collection is a quite complicated process in rural areas for various reasons. Basic municipal services are generally non-excludable and although these services 
are utilized by a majority of rural citizens, it is quite difficult for the administration to collect the user fee for services and exclude the free riders from the use of social services in the geographically scattered rural areas. Besides, rural citizens are mostly poor and cannot afford to pay user fee. It is also relatively easy to evade utility charges because the tax collection and law enforcement agencies are understaffed and are incapable of reaching out to the geographically dispersed rural users of utilities. The Provincial Secretary of Local Government and Rural Development Department based in capital city - Peshawar - commented on the issue of user fee collection:

'how do you expect a locally instituted local council gentleman to impose a tax and get it approved from a council that is local ....how can they even afford it ... this is local government's limitation'.

In urban areas, according to the Nazim of Town 3, citizens find it relatively hard to evade local taxes and user fees. Urban citizens are financially well off and generally they can afford to pay for the municipal services. Besides, the local administrations like TMAs and Union Administration can easily access and manage the geographically concentrated urban users of public utilities. In case of default, the urban citizens can also be excluded from services e.g. water supply can be stopped by Union Administration to a household in urban areas because drinking water facility is provided to fee paying registered household units. On the other hand, it is quite difficult for the Union Administration to cut the water supply to village residents. Most of the non-registered rural consumers get the water through a communal water supply source; illegal connections from main supply pipelines are also common in rural peripheries. Nazim of Town 3 in Peshawar elaborated that there are five urban Union Councils in his Town whereas all the rest are rural which are quite underdeveloped. There are 105 tube wells (for water supply) in the town 3. According to him, the TMA pays electricity bills for these tube wells which amount to approx. Rs.5 Million every month and this amount of money is generated primarily by these five urban UCs. He said that they do not have the capacity and sufficient staff to impose and collect water charges from their rural UCs; even their recurring expenses cannot be met with the revenue that is generated from all the UCs of the town. Provincial government provides them with limited resources above which the budget for their TMA would not be approved.

Suggesting a solution for the free rider problem in rural areas, Tehsil Nazim from District Swabi opined that,

'In order to convince citizens to pay the user fee, we need to make them aware of all the benefits to which they'll be entitled to. These rural communities are actively engaged in informal social services e.g. in a small village, people contribute generously and eventually collect huge 
amounts of money for construction of mosques and hujra but they are not willing to pay the water user fee.'

This shows that one of the reasons for citizens' reluctance to pay local taxes is their lack of trust in public institutions. Citizens are averse to paying taxes because they believe that due to the massive corruption in public sector departments, their tax money goes wasted. In addition, the Tehsil Nazim from Swabi explained that despite citizens' unwillingness to pay taxes, they consider the government to be responsible for providing finances for their municipal and developmental needs.

\subsection{Shortage of funds}

Given the difficulties and constraints in imposition and collection of taxes, the available resources with local governments for local development projects were reported to be very meager. Almost all respondents (local government representatives) mentioned that the limited availability of resources is a core factor that contributes towards incapacitating the institution of local government. For instance, District Naib Nazim of Swabi district lamented,

'I don't have any revenue generating resources to rely on and that's why I get funds from provincial government and it won't be an exaggeration if I tell you that the guidelines for preparing the budget for development funds is also given to us by the provincial government .... Out of that fund, 90\% is divided among our UCs and 10\% is left of District Government Secretariat .... However, one thing is for sure i.e. all the Union Councils get equal allocation in this development fund allocation... If any local government representative has personal links with higher ups such as the President or Prime minister, they invite them to their respective areas; eventually they get some development funds allocated for their area.'

Limited funds from the federal government via provinces along with the limitations in revenue collection by the local governments leave local governments vulnerable and dependent on provincial and federal grants. When the already limited developmental funds are equally divided among all the UCs of a District, the amount that is eventually received by each UC diminishes and therefore the UC administration cannot initiate significant development projects with that money. A UC Nazim from rural outskirts of Peshawar narrated that their funds are too meager to begin with. Their UC get approximately Rs.33000 per month as a grant from the District budget. Out of this amount, almost half is spent in salaries and office maintenance expenses; what is left amounts to a figure of around Rs.100000-150000 per annum for developmental projects. In addition, there are 12 members (counselors) in that UC who seldom agree upon or approve a single development project for the whole UC. Usually, every member wants this money to be equally distributed which means 
every member of UC gets around Rs.12000 (equivalent to US\$ 120 approx.) as a developmental fund per annum for a UC that includes at least a couple of villages. According to him, it was very difficult for them to make an effective use of such small amount of money. It was mentioned that support and delegation of authority from the provincial and federal government was extremely important for local governments in order to enable them to deliver public services efficiently. The same is true for funds allocation. For reasons mentioned above, the tax levying/collection domain of local governments was very limited. However, where the local representatives were influential, they could help divert the federal and provincial development funds into their areas through members of national and provincial assemblies of their respective constituencies.

\subsection{Development expenditure: Matters of duplication and jurisdiction}

In terms of the fiscal arrangements under the devolution reforms, the local government representatives of Town 3 in Peshawar complained that the provincial public departments (the ones that were not devolved under the devolution reforms) took over their revenue collection functions claiming that since such revenue generating businesses or households were in their department's 'geographical' jurisdiction, they were entitled to the revenue collection from that area. Obviously, it was a blatant infringement upon the legal functional domain of local government. It is worth noting that such incidences were observed in revenue generating functions only and not in service delivery. This means that in the case of revenue collection, the provincial or federal public departments took the geographical area into their domain but when it comes to service delivery, the local government was held responsible. The Naib Nazim of Town 3 in Peshawar district elaborated that their town was perhaps the only town in whole country where the revenue generating municipal services and other associated functions were taken into their domain by CDMD (City Development and Municipal Department) in contradiction of the rules set in LGO (Local Government Ordinance) of 2001.

Nazim of Town 3 in Peshawar explained that revenues from tax on Itwaar Bazaar (Sunday Markets), Melas (Shopping Fairs) and water supply were all included in the local government (TMA's) purview as per LGO 2001. All other assets and revenue generating functions were given to the respective TMAs but one of the main commercial roads (referring to a busy commercial road) which is the highest revenue generator (tax generating businesses located on the road), was taken over by the administration of CDMD. The same was the case with Ring road that was the highest generator of BCA fee (Building Control Authority fee - an official fee for building approvals) and revenue generated via billboards. All these taxes and fees were collected by the 
non-devolved provincial department - CDMD and the local TMA was deprived of a substantial amount of revenue to which the TMA was legally entitled. The Naib Nazim of Town 3 further explained that CDMD was legally supposed to be looking after the mega projects like construction of townships or main roads and associated infrastructure; once built, CDMD should hand it over to the local government and town administrations. A somewhat similar issue was pointed out by a UC Nazim of Swabi district, who said, 'the tax we pay to the federal government for the production and sales of tobacco from this UC is approximately Rs.21 Billion annually .... Now if this tax is redistributed in a more equitable manner, our UC and district will become a role model of development'.

All the elected members at each levels of the government in Pakistan get the development funds that are to be disbursed with their discretion. The President, Prime Minister, Chief Ministers, Senators, MNA (Members of National Assembly), MPA (Members of Provincial Assembly), Nazim and representatives of the local governments' councils get development funds in annual budgets for their respective constituencies. On this issue, District Nazim of Peshawar commented: 'in our country MNA, MPA, Senator, District Nazim, Union Council Nazim, and Union Council members are all busy in making 'sewerage system' (referring to a stereotypical development project) so what's the difference between all of them?' The same interviewee - the Nazim of Peshawar - addressing the all Khyber Pakhtunkhwa Local Government Convention in Peshawar said,

'The job of senators, MNAs and MPAs is to legislate rather eyeing the development funds. Our (local governments') task is to serve the people at the grass roots level.'

The inclusion of local governments in the disbursement of developmental funds was a major step taken in the devolution reforms and was lauded as a move towards better resource allocation. However, it was emphasized that the involvement of multiple levels of governments in the delivery of similar social services and the absence of an efficient and coherent redistributive mechanisms led to sheer wastage of resources and targeted delivery of public services at the expense of under-provision of public goods and services to other deprived areas.

Table 2: Major Findings from Interviews

\begin{tabular}{|c|c|c|c|c|}
\hline & Peshawar & Swabi & Abbottabad & Mansehra \\
\hline $\begin{array}{c}\text { Impact of } \\
\text { rural-urban } \\
\text { administrative } \\
\text { integration }\end{array}$ & $\begin{array}{c}\text { - Some urban } \\
\text { UCs were af- } \\
\text { fected negatively } \\
\text { while rural UCs } \\
\text { benefited }\end{array}$ & $\begin{array}{c}\text { - Rural UCs were } \\
\text { affected nega- } \\
\text { tively }\end{array}$ & $\begin{array}{c}\text { - Mixed impact } \\
\text { on rural and } \\
\text { urban UCs }\end{array}$ & $\begin{array}{c}\text { - Rural UC's were } \\
\text { affected nega- } \\
\text { tively }\end{array}$ \\
& & & \\
\hline
\end{tabular}




\begin{tabular}{|c|c|c|c|c|}
\hline $\begin{array}{l}\text { Impact of fiscal } \\
\text { restructuring }\end{array}$ & $\begin{array}{l}\text { - Despite the } \\
\text { general lack of } \\
\text { resources, the } \\
\text { previously mar- } \\
\text { ginalized areas } \\
\text { received funds for } \\
\text { development }\end{array}$ & $\begin{array}{l}\text { - Local govern- } \\
\text { ment system } \\
\text { filled in a } \\
\text { political vacuum } \\
\text { and the District } \\
\text { government was } \\
\text { instrumental in } \\
\text { diverting federal } \\
\text { funds to the pre- } \\
\text { viously deprived } \\
\text { areas }\end{array}$ & $\begin{array}{l}\text { - Despite the } \\
\text { general lack of } \\
\text { resources, redistri- } \\
\text { bution was more } \\
\text { evenly rationed }\end{array}$ & $\begin{array}{l}\text { - Funds directed } \\
\text { from federal } \\
\text { budget and } \\
\text { other national } \\
\text { development pro- } \\
\text { grams with the } \\
\text { involvement of } \\
\text { local governments }\end{array}$ \\
\hline $\begin{array}{l}\text { Revenue gener- } \\
\text { ation by local } \\
\text { government }\end{array}$ & $\begin{array}{l}\text { - Major revenue } \\
\text { raising functions } \\
\text { were retained by } \\
\text { the provincial } \\
\text { and federal gov- } \\
\text { ernments } \\
\text { - User fee collec- } \\
\text { tion was better in } \\
\text { Urban UCs but } \\
\text { almost negligible } \\
\text { in rural areas }\end{array}$ & $\begin{array}{l}\text { - Major revenue } \\
\text { raising functions } \\
\text { were retained by } \\
\text { provincial and } \\
\text { federal govern- } \\
\text { ments } \\
\text { - Tehsils' income } \\
\text { was better due to } \\
\text { the frequency of } \\
\text { sale of agricultur- } \\
\text { al land } \\
\text { - User fee collec- } \\
\text { tion was almost } \\
\text { negligible }\end{array}$ & $\begin{array}{l}\text { - Major revenue } \\
\text { raising functions } \\
\text { were retained by } \\
\text { provincial and } \\
\text { federal govern- } \\
\text { ments } \\
\text { - User fee collec- } \\
\text { tion was better in } \\
\text { Urban UCs but } \\
\text { almost negligible } \\
\text { in rural areas }\end{array}$ & $\begin{array}{c}\text { - Major revenue } \\
\text { raising functions } \\
\text { were retained by } \\
\text { provincial and } \\
\text { federal govern- } \\
\text { ments } \\
\text { - Tehsils' income } \\
\text { was better due to } \\
\text { the frequency of } \\
\text { sale of agricultur- } \\
\text { al land } \\
\text { - User fee collec- } \\
\text { tion was almost } \\
\text { negligible }\end{array}$ \\
\hline
\end{tabular}

\section{Conclusion}

Despite the massive rhetoric of devolution of the administrative, political and fiscal powers, the autonomy and authority of local government representatives remained limited by and large. Civil bureaucracy administered through the federal and provincial secretariats, continued to dominate the affairs of local governance and social services delivery. The fiscal policy of decentralization program was observed by policy analysts to be ineffective as the provincial governments continued to retain their influence in resource allocation to the local governments. The mechanism of provincial finance award and the rules of funds allocation for recurring and development expenses allowed negligible fiscal autonomy to the local governments. Even within the limited fiscal autonomy granted to the local councils, it was learnt that the appointed officials and bureaucrats rather than the elected members dominated the budget allocation process. Besides that, scarcity of public funds and revenue generating resources also severely undermined the fiscal efficiency of the local governments. From the limited funds allocated to the local governments, approximately $80 \%$ was pre-allocated for 
recurring administrative expenses while the remaining $20 \%$ was found to be too scant for any productive developmental project.

In order to reduce the involvement of multiple levels of government in provision of similar social services, it is argued that the federal and provincial development funds for municipal services were supposed to be allocated to the UC administration via District governments on a priority basis. In addition, the role of national and provincial legislators needs confinement to their core function i.e. legislation making and supervision of the public departments working under their respective federal and provincial ministries. The mechanism of PFC award was perceived in different ways depending on its varied outcomes in different cases. The limited funds allocated to the local governments mainly covered their recurring and administrative expenses and hence a very insignificant proportion from the PFC award was left for developmental projects. Although the distribution of the PFC award among the Towns and UCs of Districts was quite equitable in terms of policy and practice, the total amount of funds for local administrations was reported to be insignificant.

The fiscal restructuring policy of the local government reforms had an adverse impact on the local administrations' revenue generation capacities in general. The abolishment of rural-urban administrative division however, had a mixed impact on the revenue generation capacity of the local governments. In some rural Tehsils of Mansehra, more taxes were generated due to the high frequency of purchase and sale of immovable property (especially agricultural land). Contrary to that, in case of Town 3 of Peshawar and Tehsil Havailian of Abbottabad, the total amount of revenue generated was low mainly because of less frequent sale of immovable property and tax evasion (user fee of basic utilities and municipal services) in the rural UCs included in the Towns. Full-scale institutionalization and permanent establishment of local government can therefore serve as a solution to the problems of revenue collection from rural areas. In order to include the rural masses into the tax net and broaden the tax base, building of taxpayers' trust in their local institutions is extremely essential.

\section{Recent Developments and Way Forward}

As a part of a landmark political development in form of $18^{\text {th }}$ amendment in constitution of Pakistan, the subject of local governments' establishment and administration was explicitly brought into the domain of provincial government in year 2010. Following the amendment, Pakistan Tehreek-e-Insaf (PTI) led government revived the local government system and passed the Local Government Act in Khyber Pakhtunkhwa assembly in 2013. A couple of years later, the Khyber Pakhtunkhwa government conducted elections for local government on 30 May, 2015 and promulgated its rules of business in November 2015. In effect, the local governments were non-existent and 
non-functional between 2009 and 2015; technically, the local representatives started working as a third tier of government in 2016. Some major changes were incorporated in fiscal mechanisms of these reforms. In 2016, the Khyber Pakhtunkhwa Local Government and Rural Development Department notified budget rules for all three tiers of local government system in Khyber Pakhtunkhwa. Deputy Commissioners in all districts were assigned with the responsibilities of oversight, guidance on the budget's preparation, and its submission to the district governments. The Deputy Commissioners remain the Principal Accounting Officers of the respective district governments. The budget rules have been formulated for the District government, Tehsil Municipal Administration, and Village/Neighbourhood councils.

Meagre availability of resources for development projects from Annual Development Plan (ADP) money was one of the key limitations in previous reforms as mentioned. As a drastic change in policy for development expenditure, share of budget pre-allocated for non-recurring development projects was increased significantly. PFC award document published online by the Finance Department of Khyber Pakhtunkhwa describes that under the provision of Section 53 of LG Act 2013, the Development Grant to local governments shall not be less than $30 \%$ of the total development budget of the province. This is a sea change in the process of financially empowering local governments. The Provincial Government has allocated a sum of Rs.33.900 billion as District ADP for Khyber Pakhtunkhwa. Out of this, Rs.5.670 billion is subject to actual materialization of resources and Rs.28.230 billion is transferable as District Development Grant to local governments for their requirements in the financial year 2016-17. Unlike fiscal dispensation formulated and practiced in reforms of 2001, the lowest tier of local government i.e. village/neighbourhood councils get the largest chunk in development budget from ADP as can be seen in the tier-wise break up of District Development Funds in Table 3.

Table 3: Tier-wise break up of District Development Funds

\begin{tabular}{|c|c|c|c|}
\hline S. No. & Provision For & B.Es 2016-17 & Transferrable (Rs. In Billion) \\
\hline 1 & Districts & 10.400 & 8.660 \\
\hline 2 & Tehsil (TMAs) & 10.400 & 8.660 \\
\hline 3 & Village Councils/Neighborhood Councils & 13.100 & 10.910 \\
\hline \multicolumn{2}{|c|}{ Total } & 33.900 & 28.230 \\
\hline
\end{tabular}

Source: Government of Khyber Pakhtunhwa, Finance Department http://www.financekpp.gov. pk/FD/attachments/article/304/PFC-Award-2016-17.pdf 
On the other hand however, statistics reveal two trends; 1) the gradually diminishing chunk for development grants and 2) targeted distribution of development funds ignoring the PFC award formula that takes into account the population, backwardness and lag in infrastructure as criteria for development funds allocation. According to Ali (2016), Khyber Pakhtunkhwa government has allocated Rs.161 billion for 2016-17 ADP which is 8\% smaller than the ADP allocation last year. Similarly, a bureau report published in national daily - Dawn ("KP's new budget", 2016) refers to a press conference by a civil society organization that analysed the provincial budget of Khyber Pakhtunkhwa for year 2016-17. The reports explains the budgetary allocations fails to allocate 'not less than 30\%' of the total development budget for local governments; the allocated amount for local governments in the districts, tehsils, villages and neighbourhoods is $21.06 \%$ of the total development outlay of Rs.161 billion. Fair distribution of resources among the districts was also questioned. Rs.5.1 billion or $3.22 \%$ of the total development funds was allocated for Nowshera - the home district of Chief Minister Pervez Khattak. This was compared with the allocation of only Rs.4.47 billion or $2.78 \%$ of the total development budget to seven chronically poor southern districts of Bannu, Dera Ismail Khan, Hangu, Karak, Kohat, Lakki Marwat and Tank. The Hazara region consisting of six districts of Abbottabad, Haripur, Battagram, Mansehra, Kohistan and Torghar also lagged behind with a cumulative allocation of only Rs.4.54 billion or $2.82 \%$ of the total development outlay. The southern districts were allocated $3.2 \%$ and Hazara 3.1 per cent of the total development outlay in 2015-16. These are reduced to $2.78 \%$ and $2.82 \%$, respectively, in 2016-17. In addition, 'block' grants also showed an upward trend as compared to the preceding year i.e. $71 \%$ in $2015-16$ and $73.56 \%$ in $2016-17$.

Although it is too early to assess the impact of most recent reforms, this study concludes with identification of two major positive changes in the current fiscal management system of local government. First, the significant increase (30\%) in the proportion of development grants from ADP is likely to support social infrastructure building in the province. Secondly, the Village/Neighbourhood councils - the lowest tier of local governments - are now recipients of the largest chunk of earmarked development funds. Consideration in letter and spirit, of backwardness and lag in infrastructure in addition to population of districts, will help reduce the economic and social inequalities between diverse regions of KP. In this regard, nation-wide population census conducted in March 2017 will be instrumental for development planning. On the other hand, no comprehensive strategy has been designed or practiced to improve own- source revenue generation by the local governments. Representatives of local governments are empowered in a sense that they have more funds to spend on local development projects however they remain totally dependent on fiscal grants from PFC which continues to be over-represented and dominated by provincial bureaucra- 
cy and provincial government. That is why local representatives are likely to remain dis-incentivized to enhance revenues through local taxes. The impact of structural changes in fiscal management system of recent reforms can be assessed in a similar study preferably conducted at the end of the first term of local governments in 2019.

\section{References}

Ajaz, T., \& Ahmad, E. (2010). The effect of corruption and governance on tax revenues. The Pakistan Development Review, 49(4), 405-417.

Ali, M. (2016, June 15). KP budget 2016-17: Development spending cut by 8pc to Rs161bn. Dawn, Retrieved from www.dawn.com/news/1264877

Bardhan, P. (2002). Decentralization of governance and development. The Journal of Economic Perspectives, 16(4), 185-205.

Bardhan, P., \& Mookherjee, D. (2006). Decentralization, corruption and government accountability: An overview. In S. Rose-Ackerman (ed.). Handbook of economic corruption. (pp. 161-188). Cheltenham: Edward Elgar.

Charlton, J., Ebel, R., Mukhtar, H., Scott, R., \& Vaillancourt, F. (2002). Pakistan Devolution: A note in support of the development policy review. World Bank and the Netherlands Ministry of Foreign Affairs. Retrieved from http://himayatullah.weebly.com/uploads/5/3/4/0/53400977/brief_history_of_musharaf_devolution_plan_muhammad_ijaz.pdf

Cheema, A., Khwaja, A., \& Qadir, A. (2005). Decentralization in Pakistan: Context, contents and causes. Faculty Research Working Paper Series No. RWP05-034, John F. Kennedy School of Government, Harvard University. Retrieved from http://unpan1.un.org/intradoc/groups/public/documents/ apcity/unpan027225.pdf

Cyan, M., \& Porter, D. (2004). Innovations under constraint: Local governments and service delivery in Pakistan. Paper presented at Asian Development Bank Regional Seminar on Pro-Poor Service Delivery, Manila. 10-12 February 2004.

Cyan, M. (2007). Fiscal architecture: A fetter on new local governments in Pakistan? International Journal of Public Administration, 30(12), 1459-1483.

De Mello, L., \& Barenstein, M. (2001). Fiscal decentralization and governance - A cross country analysis. IMF Working Paper No. 01/71. Retrieved from http://www.imf.org/external/pubs/ft/wp/2001/ wp0171.pdf

Government of Pakistan (2001 and 2005). Manual of local government. The Northwest Frontier Province Local Government, Elections and Rural Development Department, Peshawar, Pakistan.

Government of Pakistan (1973) Constitution of Islamic Republic of Pakistan. Retrieved from http://www. pakistani.org/pakistan/constitution/ 
Hasnain, Z. (2008). Devolution, accountability, and service delivery: Some insights from Pakistan. Policy Research Working Paper No. 4610. The World Bank South Asia Region Poverty Reduction Economic Management Department. Retrieved from https://openknowledge.worldbank.org/handle/10986/6713

Huther, J., \& Shah, A. (1998). A simple measure of good governance and its application to the debate on fiscal decentralization. World Bank Policy Research Working Paper Series No. 1498. Washington DC: The World Bank.

ICG (2004). Devolution in Pakistan: Reform or regression. International Crises Group Report No. 77. Islamabad/Brussels. Retrieved from https://www.crisisgroup.org/asia/south-asia/pakistan/devolution-pakistan-reform-or-regression-0

Jones, G. W. (1978). Central-local government relations: Grants, local responsibility and minimum standards. In D. Butler \& A. H. Hulsey (eds.). Policy and politics: Essays in honor of Norman Chester (pp.66-81). London: Macmillan.

Khemani, S. (2004). Local government accountability for service delivery in Nigeria. Washington DC: World Bank Development Research Group. Retrieved from http://siteresources.worldbank.org/INTPUBSERV/Resources/stuti_nigeria.pdf

Khan, M. Z. (2017, February 13). KP struggling with a new equitable PFC formula. Dawn. Retrieved from https://www.dawn.com/news/1314514

KP's new budget- unclear priorities, unfair allocations. (2016, June 23). Dawn. Retrieved from https:// www.dawn.com/news/1266695

Nayyar-Stone, R., Ebel, R., Ignatova, S., Rashid, K., Hatry, H., \& Peterson, G. (2006). Assessing the impact of devolution on healthcare and education in Pakistan. Paper prepared for Pakistan Devolution Support Project. United States Agency for International Development, Washington DC: The Urban Institute. Retrieved from http://www.urban.org/uploadedPDF/411318_pakistan_project.pdf

Rodden, J. (2002). The dilemma of fiscal federalism: Intergovernmental grants and fiscal performance around the world. American Journal of Political Science, 46(3), 670-687.

Smith, B. C. (1985). Decentralization: The territorial dimension of the State. London: George Allan and Unwin.

Williamson, T., Ahmad, M., \& Smith, S. (2005). Improving devolved social services delivery in N.W.F.P and Punjab. Islamabad: Asian Development Bank.

Water and Sanitation Program for South Asia. (1999). Municipal Management and Finance in Southern Punjab. Volume 2: City Reports for Four Municipalities - Khanpur, Rahimyar Khan, Sadiqabad, and Dera Ghazi Khan. Retrieved from https://www.wsp.org/sites/wsp.org/files/publications/51200752257_ Volume_II_City_Reports_of_Four_Municipalities_Part_1.pdf 
